\title{
Voler + infinitive in Catalan: From the imminence aspectual periphrasis to the epistemic and evidential marker (from the 13th century to the present day)*
}

\author{
Jordi M. Antolí Martínez \\ Universitat d'Alacant. ISIC-IVITRA \\ jordi.antoli@ua.es
}

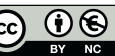

Received: May 22, 2015

Accepted: September 14, 2015

\begin{abstract}
Today's Catalan knows the phrases vol ploure and vol caure, literally '[it] wants to rain' and '[it] wants to fall,' with the meaning of 'showing signs that [something] has to [happen]' (DDLC, s.v. voler). Such structures are only a remainder from the imminence aspectual periphrasis voler + infinitive, present in old and modern Catalan, as well as in other Romance languages, at least in medieval times (such as Occitan, Franco-Provençal, French or Italian). Our aim in this study is trying to describe and explain the constructionalization process (following Traugott 2012 and Traugott \& Trousdale 2013) whereby this structure, saturated with the infinitives ploure or caure, will assume an epistemic/evidential value ever since the Modern Era (17th and 18th centuries) which is the one known by the current language. From Classical Latin and up to present-day Catalan, the periphrasis will thus describe a trend Wish $>$ Intention $>$ Imminence $>$ Epistemicity/ Evidentiality.
\end{abstract}

Keywords: Old and Modern Catalan; evidenciality; invited inferencing; voler + infinitive; imminence periphrasis.

* The present paper forms part of the research project «L'evidencialitat en català antic: estudi de corpus $i$ acostament segons la gramàtica cognitiva [Evidentiality in Old Catalan: corpus study and approach from cognitive grammar]», within the framework of the grant FPU12/05373 of the Spanish Government's Ministry of Education under the direction of Prof. Dr. Josep Martines i Peres. It is additionally included in the matrix of the Instituto Superior de Investigación Cooperativa [Higher Cooperative Research Institute] IVITRA [ISIC-IVITRA: $<$ http://www.ivitra.ua.es>] (Ref. ISIC/2012/022) and in the activity of the competitive projects PROMETEOII/2014/018 (Prometheus Programme of the Generalitat Valenciana [Valencian Autonomous Government] for Research Groups of Excellence in R\&D, co-financed by the UE's ERDF), FFI2012-37103-FILO, IVITRA-IEC/PT2008-S0406-MARTINES01, 2008-2010 PT2012S04-MARTINES, GITE-09009-UA, USI-045-UA, VIGROB-125.

I would like to express my recognition and thankfulness to Dr. Josep Martines, who has opened with his studies a line of research on evidentiality and the expression of future that this paper seeks to continue. 
Resum. Voler + infinitiu en català: de la perífrasi aspectual d'imminència al marcador epistèmic i evidencial (del segle XIII a l'actualitat)

El català actual coneix les locucions vol ploure i vol caure, amb el significat 'presentar indicis que ha de [esdevenir-se alguna cosa]' (DDLC, s.v. voler, 5). Aquestes estructures són solament una resta de la perífrasi aspectual d'imminència voler + infinitiu present en català antic i modern, així com en altres llengües romàniques, si més no en època medieval (com l'occità, el francoprovençal, el francès o l'italià). En aquest estudi provem de descriure i explicar el procés de construccionalització (seguint Traugott 2012 i Traugott i Trousdale 2013) pel qual aquest estructura, saturada amb els infinitius ploure o caure, assumirà un valor epistèmic/evidencial des d'època moderna (segles XVII i XVIII), que és el que coneix la llengua actual. D'aquesta manera, la perífrasi descriurà, des del llatí clàssic i fins al català actual, una tendència Desig > Intenció > Imminència $>$ Epistemicitat/Evidencialitat.

Paraules clau: català antic i modern; evidencialitat; inferència invitada; voler + infinitiu; perífrasi d'imminència.

\section{Table of Contents}

1. Introduction

2. From the expression of volition to the expression of future

3. The evolution in Latin. From volition to imminence
4. The evolution in Catalan. From the imminence aspectual periphrasis to the epistemic/evidential marker

\section{Conclusions}

References

\section{Introduction}

One of the classical issues in historical morphosyntax is the replacement -in the passage from Latin to Romance languages- of the synthetic future by initially modal periphrases and the grammaticalization processes that they followed (see Fleischman 1982; in Catalan, Pérez-Saldanya 1998; about the origin of epistemic future, Martines forthcoming $b$; about the prospective value of deure + infinitive in Old Catalan, Sentí 2010: 114-118, Schmid 2012). These periphrases are formed by the Latin modals DEBEO, EO, VENIO, VOLO and HABEO; the triumph of this last verb, HABEO, as a future auxiliary will not prevent the survival of other periphrases in parallel, as is the case of ir $a+$ infinitive, in Spanish, or aller + infinitive in French. And such alternative periphrases have been successful on specific occasions, as it happens in Logudorese Sardinian, a language where the future is formed with an auxiliary derived from DEBEO. More precisely, in the case of VOLO, it has only given rise to the Romanian periphrastic future; this solution may have been successful as a result of the influence exerted by the Balcanic context, even though it must be said in any case that such influence would have favored a patrimonial construction (Schulte 2007: 286) which left a trace in many other Romance languages as well.

Our aim in this paper is to follow the evolution in Old Catalan (from the earliest texts to the 16th century), Modern Catalan (from 1601 to the beginning of the cod- 
ing process with the Renaixença), and Contemporary Catalan (from the Renaixença to the present day), suffered by one of these periphrases different from the one constituted by HABEO and which, despite not having succeeded as a future marker, will eventually develop a prospective value. It is the periphrasis [voler Vinf] of which there is evidence in Old and Modern Catalan with an imminence aspectual value (DECat, 377, 30-43a; DAguiló; DFaraudo) and which can only be found in Contemporary Catalan saturated with the infinitives ploure 'to rain' and caure 'to fall' ( $D C V B$, s.v. voler, 5; DIEC2, s.v. voler, 7; DDLC, s.v. voler, 5), whereas the collocation with other verbs is rare (Gavarró and Laca 2002: 2695) and perhaps typical of literary language. ${ }^{1}$ The auxiliary verb is used with the imperfective aspect (in present or imperfect tense). In today's Catalan, the expression of imminence is made by means of the Romance periphrasis anar $a+$ inf. and also estar a punt de + inf.; the periphrases estar per + inf. or anar per + inf. are more unusual, though by no means unknown (Gavarró and Laca: 2694-2695).

The interest in the analysis of [voler Vinf] in Catalan is explained by the fact that, from a diachronic point of view, it shows a grammaticalization process which had already been operating in Classical Latin -to which the volitive periphrasis is known- that continues in Medieval Catalan with the appearance of the imminence periphrasis and finishes in Modern Catalan with the saturation of the construction with the infinitives ploure ('to rain') and caure ('to fall'), and with the semantic re-analysis of the whole, which will stop expressing imminence to express prediction. Thus, in accordance with our proposal, the constructions voler ploure and voler caure are remainders of the aspectual periphrasis [voler Vinf] of the old and modern language but re-analyzed semantically with an epistemic/evidential value.

Amongst the other languages which have come to develop an imminence aspectual periphrasis with the derivatives of volo + infinitive stands out French; it appears in the Medieval language (DGodefroy, s.v. voleir; $D M F$, s.v. vouloir IV.A.1), whereas it has been removed from the reference model in the contemporary language (DAcadémie), and the $\operatorname{TILF}(\mathrm{B}, 4)$ categorizes it as «vieilli ou régional» and offers weather-related examples close to today's Catalan vol ploure: le temps veut changer, il veut pleuvoir, il veut faire beau. ${ }^{2}$ In current Occitan, the same as in Catalan, the periphrasis only survives saturated with the infinitive ploure, according to DCantalausa or Dicod'Òc (s.v. voler): Cresi que vòl plòre. Prospective uses of [voler Vinf] (Provenzalisches Supplement, s.v. voler, 21; DLevy, s.v. voler: 'être sur le point de') can be found in Old Occitan as well. The most interesting case is provided by Italian, a language in which the periphrasis survives to the present day, and it does so not only with an imminence value but also with the epistemic/evidential meaning proposed here for Catalan: 'sempre senza

1. Gavarró \& Laca collect an example of voler with another infinitive: voler esqueixar-se ('desgarrarse') in Rodoreda: «una branca [...] va cruixir com si volgués esqueixar-se» (Rodoreda, Quanta guerra, 174; apud Gavarró i Laca 2002: 2695), although it is a possibility categorized as rare.

2. In fact, some of the examples where it appears were taken from the dialect of Geneva and would therefore correspond to Franco-Provençal: «Nous mettons il veut devant un infinitif, pour marquer le futur. Il veut pleuvoir, il veut faire beau (J. Humbert, Nouv. gloss. genev., 1852: 2)». 
idea di volontà, per indicare l'imminenza di qualche cosa, o la certezza, la probabilità che tra poco una cosa accada': vuol piovere, mi pare; vuol essere un'annata dura, questa; eh, vuol essere una faccenda seria! (VTreccanni, s.v. sentire, 6b; see also también GDIU, s.v. volere, 13 and 14). For a more comprehensive overview on the Romance evolutions of VOLO + infinitive with a prospective value, consult the summary carried out by Sentí (2013: 131-132).

\section{From the expression of volition to the expression of future}

Bybee, Pagliuca and Perkins (1994: 243-279) point out in a contrastive study about the origin of the expression of future that, together with the 'obligation' or the 'movement', amongst others, the 'desire' is a notion from which future can develop (1994: 254-257). More precisely, and from a diachronic perspective, it is suggested that the process follows these stages:

\section{DESIRE $>$ WILLINGNESS $>$ INTENTION $>$ PREDICTION}

This process is illustrated, amongst others, by the auxiliary will of present-day English. In Old English, willan was a semantically full and argumentally transitive verb in its origin which selected noun or infinitive objects, and which expressed volition. In Medieval English (12th to 15th centuries), it became an auxiliary which expressed intention and has come to our times grammaticalized as a clitic future marker, with the consequent alterations, also formal ones (phonologically speaking, it becomes an unstressed -often contracted-form).

In accordance with the proposal made by Aijmer (1985), the origin of this temporal -future- value of will results from a gradual process where semantic re-analysis makes it possible to go from the notion of 'desire' to that of 'intention' and finally 'future.' In this author's opinion, the incorporation of the intention value must have begun in first-person contexts: «If the speaker is willing to do something, it follows conversationally that he intends to do it and that the future action will take place» (Aijmer, 1985: 13); a special mention deserves to be made of the examples where 'to want' is equivalent to 'to accept' someone else's proposal, assuming the desire of others (as in the response to an offer, invitation, etc.). However, the passage from the volitive/intentional value to the future time value must have happened in third-person contexts, through the extension in the use of the verb with progressively [-human] subjects (for example, non-human animate beings, personifications...) where the interpretation in a volitive sense is not possible.

In turn, Traugott (1989) picks up the grammaticalization of will in a study about the appearance of the epistemic meaning in English. As a novelty, it is worth highlighting that this change is placed within the context of the subjectivization process, following trend III of the semantic change proposed by this author: the meaning progressively tends to be based on the speaker's subjective belief about the proposition; it results from the coding of conversational implicatures (a process that will be systematized in the Invited Inferencing Theory of Semantic Change, 
IITSC). Broadly speaking, this author structures the coding process for epistemic meanings with the following scheme (1989: 43):

\section{FULL VERB $>$ PREMODAL VERB $>$ DEONTIC $>$ WEAK EPISTEMICITY $>$ STRONG EPISTEMICITY}

She consequently suggests that volition gives rise to intention as an implicature, and after this new value has been coded, there is a passage to the conversational implicature that the future action will happen (Traugott 1989: 50-51).

Following this line of research exposed in other works (Hopper and Traugott 1993, Traugott and Dasher 2002), studies like that of Martines (forthcoming $b$ ) show the hypothesis already put forward, amongst others, by Bybee, Pagliuca and Perkins (1991: 32) according to which the epistemic value derives from the temporal future; in this case, Martines explains it as a result of an invited inferences game applying Traugott's Invited Inferencing Theory of Semantic Change (IITSC) (2012). The scheme would thus be shaped as follows:

\section{DESIRE $>$ INTENTION $>$ FUTURE $>$ EPISTEMIC MODALITY}

Nevertheless, with the exception of Romanian, the Romance evolutions of VOLO + infinitive will not give rise to the general temporal value of future but to an imminent future; as has already been pointed out, [VOLER Vinf] will become an imminence aspectual periphrasis in Old Catalan. ${ }^{3}$ Therefore and since, as will be seen in the following chapters, [voler Vinf] does not properly express futurity, it seems pertinent to introduce the concept of prospective aspect, applied by Martines (forthcoming $b$ ) to the study of epistemic future in Medieval Catalan, and by Narrog (2012: 278) to the study of the English construction to be about to. According to this last author, «The prospective [...] is an aspectual category describing the transition from a current state to some subsequent event, which also has temporal, modal, and evidential features» (Narrog 2012: 278). He also refers to the semantic trip of will and proposes this trend (Narrog 2012: 280):

\section{PROSPECTIVE $>$ FUTURE $>$ PROBABILITY}

He additionally verifies the trend INTENTION > PROSPECTIVE (Narrog 2012: 281-282). This triple characterization -temporal, modal (epistemic in our case) and evidential- is much better suited to the reality of the phenomenon under study in this paper, and it explains much better the reason for the process followed. Enriching the schemes by Traugott (1989) and Bybee (1994) with these elements, the semantic change process to be suggested next is the following one:

3. In relation to this issue, Bybee, Pagliuca \& Perkins (1994: 271) state that very often «the use of immediate future is diagnostic of a simple future at an earlier stage of its development,» as would be shown, for instance, by the fact that periphrastic formulas are mostly used to express it, and not morphemes, as it happens in the case of the simple future. 


\section{[I] DESIRE $>$ INTENTION $>$ [II] IMMINENCE (PROSPECTIVE ASPECT) $>$ [III] EPISTEMIC MODALITY / EVIDENTIALITY}

This model will now be applied to the study of the construction [voler Vinf]: from the Latin origin of the volitive periphrasis (\$3.1.) to the origin, already in Romance times and, more specifically in Medieval Catalan, of the imminence aspectual periphrasis (\$3.2.), and finally to the re-analysis of the construction with a modal/evidential value (§3.3.).

\section{The evolution in Latin. From volition to imminence}

The verb volo, accompanied by infinitive, forms a volitive periphrasis in Classical Latin which has as its semantic nucleus the meaning of 'to wish' (DLewis, s.v. VOLO, 1): «potare ego hodie tecum volo» (Plaut. Aul. 3, 6, 33; apud DLewis, s.v. volo). Therefore:

(A) The subject is an 'experiencer,' animate and prototypically human.

(B) The verb expresses a mental, volitive state.

(C) The infinitive subordinate, the theme, describes the desired situation.

A second generic meaning derives from the first one: 'having the intention to do something' (DLewis, s.v. Volo, 1c): «eadem quae illis voluisti facere tu, faciunt tibi» (Plaut. Mil. 3, 1, 11). What is new this time is that the subject not only experiences a desire in a passive way, instead the will makes the subject decide to facilitate the advent of the desired situation. Therefore, in terms of lexical aspect (Pérez-Saldanya 2002: §22.3.2, following Vendler 1957), there is a change from a mental state which lacks an inherent goal to a realization which has a defined goal (the achievement of a desired situation) which can entail the subject's physical action to achieve that goal.

And, finally, there are a number of meanings linked to the expression of future ('to be going to', 'to be about to, on the point of', 'will'; DLewis, s.v. volo, $1 \mathrm{f}$, $\mathrm{g}, \mathrm{h}$ ), especially the immediate one. Those meanings must be understood as the result of contextual inferences such as the one described by Aijmer (1985: 13): «if the speaker [says he] is willing to do something, it follows conversationally that he intends to do it and the future action will take place».

(1) a. [...] haec argumenta ego aedificiis dixi; nunc etiam volo docere ut homines aedium esse similes arbitremini 'I am going to show how' (Plaut. Most. 1, 2, 37; apud DLewis, s.v. volo)

b. [...] animum advortite: Comediai nomen dari vobis volo, 'I will give you', etc. (Plaut. Cas. prol. 30; apud DLewis, s.v. volo)

The possibility that the periphrasis with the verb volo might develop a prospective value is consequently based, on the one hand, on the dislocation existing 
between the desire expressed and its potential satisfaction, necessarily future (or rather subsequent to the reference point, the present speech act or the point in the past); and, on the other hand, on the determination of the subject who has the ability to fulfill the desire and therefore makes the prediction possible. The fact of expressing the will (understood as the sum of desire and intention) therefore implies introducing three more components following the characterization made by Narrog (2012: 278): the temporal one, since a future world is described; the epistemic modal component, insofar as this world is only possible; and the evidential one because, after all, speaking about the future is to refer to prediction, to inference.

Nevertheless, as shown by the preceding examples, it cannot be concluded that the periphrasis with vOLO already had a temporal value in Classical Latin. In the cases found during our study, the verb is still closely linked to the expression of the first meaning, volitive; Pinkster (1985) concludes in his study about the development of future auxiliaries in Latin (1985) that:

[...] it must be said that there is no evidence whatsoever in our texts for the development of VELLE as an auxiliary in Latin. The internal structure of the predication to which VELLE belongs remains constant in the course of history. The subjects of VELLE are human Agents who are in control of an action or position denoted by that verb that occurs as its complement [...] (Pinkster 1985: 190)

In other words, it must have been in the Romance Era, during the pre-literary period, when the various Romance derivatives of volo became future auxiliaries (Pinkster 1985: 187).

\section{The evolution in Catalan. From the imminence aspectual periphrasis to the epistemic/evidential marker ${ }^{4}$}

\subsection{The blurred border between intention and imminence. The subject's potential agentivity}

Ever since the first texts of the 13th century in Catalan, voler acts as an auxiliary in two periphrases. One is the volitive periphrasis that could be identified in Latin (see, for fifteenth-century Catalan, Schmid 2012); the second one is the aspectual periphrasis, from a preparatory or initial phase of a prospective nature (see an overview of aspectual periphrases for Old Catalan by Montserrat 2012 and one for modern Catalan by Gavarró and Laca 2002). The first examples found in our corpus are the following ones $(2 \mathrm{a}-\mathrm{c})$ :

4. This study was based on analyzing examples of the construction [voler Vinf] obtained from the Corpus Informatitzat de la Gramàtica del Català Antic (s. XIII-XIV) and from the Corpus Informatitzat de la Gramàtica del Català Modern (CIGCMod). 
(2) a. E, quant fo ora de vespres, Sent Joan manà e fé dir per l'arcevesque $a \cdot n$ Patrici, dién:- - Séyer, lo sol és en so que-s vol colgar- (Vides de sants rosselloneses [s. XIIIb], 198, 20)

'And when it was the hour of vespers, Saint John commanded and made the archbishop say to Patrick, saying: -Lord, the sun is on the spot where it wants to set' ${ }^{5}$

b. Si paretz o cases d'alcun o cuberta de cases o murs de la ciutat minantur ruina, so és que volen caure o estan en reech de caure, a coneguda d' uns e d' altres aquel qui a temor que càgia, ven e deu venir a la cort, e aquí mostrar com aqueles paretz, cases o cuberta o murs minantur ruina, e que seria gran dan d' él e d' altres [...]. Con sia desús dit que si cases d' alcun veyn minantur ruinam, so és que si les dites cases volen caure e que sien en rech de caure $[\ldots]$ per sentència dels ciutadans coven que $\cdot 1$ demanat dón fermansa, mal son grat, al demanador, que si dón vènia al demanador que lo y emén e lo y refassa, o que derroch la paret o cuberta o alò que vol caure [...]. (Costums de Tortosa [s. XIIIb], 166)

'If someone's walls or houses or the roof of the houses or walls of the town minantur ruina, that is, which want to fall or are in risk of falling, for the knowledge of ones and the others, anyone who fears that it might fall, they should and must go to court, and show here how those walls, houses or roof or walls minantur ruina; expressed differently, that if the aforesaid houses want to fall and are in risk of falling [...] by a sentence of the citizens it is advisable for the defendant to give guarantees, despite himself, to the plaintiff, that if he gives permission to the plaintiff, he should repair it and rebuild it, or he should knock down the wall or roof or whatever wants to fall'

c. Fem fur nou que si negun posseirà a bona fe cosa moble o no moble e en aquella cosa farà necessàries despeses e profitables, ço és a saber, que curarà e sanarà lo catiu $\mathrm{o} \cdot 1$ servu malaute, $\mathrm{o}$ la casa que volie caer repararà o adobarà (Furs de València [XIIIb], 52, 04)

'We make a new charter that, should nobody own a movable or immovable thing in good faith, and that he will carry out the necessary and fruitful expenses on that thing, that is, namely, that he will look after and heal the sick prisoner or servant, or will repair or fix the house which wants to fall'

As can be seen in the examples, the periphrasis marks the event immediately preceding the action described by the infinitive: colgar ('to set') the sun or caure ('to fall') a wall/roof/house.

Although it is true that recognizing this aspectual component in the periphrasis seems to be easy with examples such as the previous ones due to the inanimate nature of the grammatical subject, this differentiation is not so clear in those cases where the subject is animate and prototypically human and consequently has the

5. Our translation of the cited examples aims to provide a literal correspondence with the original. 
ability to control the situation described by the infinitive; in other words: those cases where the subject has the potential ability to achieve the realization of the situation described by the infinitive. Then it becomes difficult to draw a distinction between the periphrasis which expresses intention and that of imminence, and it very often depends on the contextual interpretation made by us. For instance, immanence cannot be interpreted in the case of (3) because the succession of events does not specify that the subjects were still not ready to start the realization of the desired action («cremar lo fenèvol»), but they were on their way.

(3) $[\ldots]$ e esgarrà $\cdot \mathrm{i} \cdot$ caval al tornar que ells se $\cdot \mathrm{n}$ faÿen can volgueren cremar lo fenèvol. (Jaume I, Llibre dels fets [s. XIIIb], 49, 6)

'and wounded a horse during the return that they made when they wanted to burn the trebuchet'

Schmid (2012: 870) gathers some examples of the periphrasis coming from the fifteenth-century novel Curial e Güelfa with a human subject and an aspectual value:

(4) a. Curial mirà envers Jacob, e viu que volia ociure a Othó. (Curial e Güelfa [s. XV], 71)

'Curial looked towards Jacob, and saw that he wanted to kill Othó'

b. li dix paraules que lo marquès havia dites d'ell en la ora que volia entrar al torneig (Curial e Güelfa [s. XV], 110)

'told him the words that the marquis had said of him at the moment when he wanted to enter into the tournament'

The interpretation as an imminence periphrasis will prove easier in those cases where that periphrasis forms part of a time subordinate introduced by quan ('when'), insofar as the adverb places the intention within a specific chronological framework, as can be seen in (5):

(5) Quan ve que una persona vol pecquar, decontinent l'àngel li diu: «Guarda, no faces tal peccat, car si $\cdot 1$ faràs, seràs difamat e perdut». (Vicent Ferrer, Sermons [s. XIVb], 74, 2)

'When he sees that one person wants to sin, the angel immediately tells them: «Wait, do not commit that sin, because if you do so, you will be defamed and lost»’'

It is worth highlighting that other highly frequent contexts which have the imminence component are the cases of attempt (presented by Gavarró and Laca when referring to aspectual periphrases; 2002: 2693), that is, those where an event is imminent but does not take place in the end: 
(6) a. E, mentre que lls seus venien, él volch metre mà al coutel, e nós enbargamlo, e no 1 pòch traure. (Jaume I, Llibre dels fets [s. XIIIb], 29, 20) 'And, while theirs were coming, he wanted to take the sword, and we stopped him from doing it and he could not take it out'

b. E, quan éls exiren de Tortosa per venir a nós, vench-los gran pluja, e ploch tant en aquela saó, que, quan volgren passar lo riu d'Uyl de Cona, no·l pòch passar sinó $\cdot \mathrm{i} \cdot$ cavaller qui passà en $\cdot \mathrm{i} \cdot$ cavall e passà nadan. (Jaume $\mathrm{I}$, Llibre dels fets [s. XIIIb], 213, 7)

'And, when they left Tortosa to come with us, a heavy rain fell upon them, and it rained so much on that occasion that when they wanted to cross the river of Uyl de Cona, only one knight who crossed it on a horse swimming could do so'

Insofar as it is interpreted that the process which will culminate in the achievement of the situation described by the infinitive has begun, these contexts are closer to imminence: the subjects of the previous sentences had undertaken actions which were meant to lead to the desired situation: taking the sword or crossing the river. However, the speaker already knows the end of this incipient realization in the narrative context, he already knows that it is a failed will, an attempt; the periphrasis codes a failed achievement and it is consequently conjugated in a perfect tense.

All the previous examples have in common the fact that an aspectual reading can be made, but the latter is invariably accompanied by the volitive reading. It is therefore impossible for us to speak about an imminence periphrasis, since the volitive reading dominates: the idea of imminence is present, but 'to try', 'to have the intention of' prevails. It will be necessary to wait for the examples in which this potential agentivity can be lessened and decrease to find the imminence periphrasis.

\subsection{The imminence aspectual periphrasis}

As anticipated above, the imminence aspectual periphrasis is already found constituted in the 13th century (examples $(2 \mathrm{a}-\mathrm{c})$ ), which means that the possible change process can only be reconstructed $a$ posteriori. There is no doubt that the coding of the imminence aspectual value, independent of intention, is only possible in those contexts where the subject's potential agentivity disappears; or expressed differently, in those contexts where the subject cannot play a role in the advent of the situation described by the infinitive. This same contextual influence is also mentioned by Aijmer (1985: 13), though restricting the context which makes impossible the change to first-person cases and suggesting that the development of the new value should start in those cases which have third-person subjects. For this reason, the examples containing a clear temporal value separated from the subject's intentionality will be found in those cases where the realization of the event does not depend on the subject's will.

The dissolution of the volitive meaning associated with this periphrasis must have taken place following a process characterized by gradualness, a semantic bleaching of the volitive value, and a semantic re-analysis with an aspectual value 
resulting from the invited inference through the context (the concepts of Traugott and Dasher 2002, Traugott 2012, and Traugott and Trousdale 2013 are applied here). The presence in our corpus of examples of several cases which act as a blurred border between volition and pure imminence, independent of intention, allows us to picture which could have been the bridging contexts that set the change in motion. The following three contexts deserve to be highlighted:

a) The volitive meaning is lessened in those contexts where usual or repetitive facts are introduced. Sentí (2013, following Schmid 2012 and Martines) speaks about a planned future, in his specific case referring to certain uses of the periphrasis deure + infinitive:

(7) a. E, quant vench que nós nos voliem gitar, ell vench; (Jaume I, Llibre dels fets [s. XIIIb], 349, 8)

'And, when we wanted to go to bed, he came'

b. Quan la prevere vol anar a offerir, veus que pren lo ensenser e ensense l'altar. (Vicent Ferrer, Sermons [s. XIVb], 93, 27)

'When the priest wants to go and offer, you see that he takes the censer and incenses the altar]

b) Also those contexts that lack a specific subject and thus come closer to impersonality, as a result of which the attribution logically remains unclear:

(8) E venguda la hora que volien dir la missa, Tirant, per major honestat sua, tramés al duch si volia venir ha hoyr missa. (Joanot Martorell, Tirant lo Blanch [s. XVb], 588, 2) ${ }^{6}$

'And once the hour when they wanted to say Mass had arrived, Tirant, for his greater honesty, ordered to ask the duke if he wanted to go and hear mass'

c) And the will is also lessened in contexts where the execution of intention is mediate and the subject acts as a means dependent on other people's will. For example, in (9) the first volch ligir does not express the will of the subject -the scribe- but that of the counsellors who entrusted him with the task; something different happens in the second case, which reflects a personal decision.

(9) Cant tuyt foren aplegats, los conselers obriren les letres e donaren-les a l'escrivà que les ligís. Cant l'escrivà volch ligir les letres, e veé que·l comte feya aytal manament contra la comtessa, duptà que no volch ligir; e apeylà los conselers a una part, e legí'ls les letres. (La fiyla del rey d'Ungria [XIVb], 49, 16) 'When everyone had gathered, the counsellors opened the letters and gave them to the scribe for him to read them. When the scribe wanted to read the letters, he saw that the count was giving that order against the countess, he doubted whether he wanted to read; called the counsellors aside and read the letters to them'

6. See this parallel example in French, coming from the $D M F$ : ... se partit monseigneur le curé de la nouvelle mariée, qui se va mettre en son siege pour oyr la devote messe que le bon curé vouldra dire. (C.N.N., c.1456-1467, 301). 
This explanation is not the only one which can be found, though. Without that being incompatible with the explanations above, there are contexts which make us think about the possible existence of another sense between 'intention' and 'imminence' -derived from the former- where neither the aspectual notion nor volition have been focused yet; there is only a vague idea of 'trajectory' or 'direction' (see example (10)) thanks to a lessening of the subject's agentivity. This has to do with the idea of 'plan,' of 'foresight,' in a broad sense, which derives from the concept of planned future described in context a) above.

(10) Alò metex s'és si les cases eren ja fetes e les rayls dels arbres de son veyn crexien tant que les coses li foradassen o li traucassen o li volgessen traucar, aqueles rayls pot lo seynor de les cases taylar e trencar [...]. (Costums de Tortosa [s. XIIIb], 167, 22)

'The same happens if the houses were already built and the roots of his neighbor's trees grew so much that they made holes on things or knocked the houses down or wanted to knock them down, the owner of the houses can cut and break those roots.'

Paying attention to the previous example, dated in the second half of the 13th century, allows us to realize that the subject is not endowed with will; however, there is no intention to focus on imminence either (the process is foreseeably long). What this tells us is simply that the root seems to follow a certain direction that will most probably end up causing damage.

It is worth highlighting that only few examples are found with a clearly aspectual value; on the one hand, there is the problem of volitive interpretation in those cases where the subject is [human] and can control the action described by the infinitive. On the other hand, it may be an element with a colloquial connotation and highly influenced by the enunciation context (since it expresses immediacy) and this is why the first examples are found in narrative texts (Vides de sants, Recull d'exemples), often with a markedly oral nature (such as the sermons of Vicent Ferrer). That determines the chronology which can be given for the process and forces us to consider it provisional. Therefore, the first verbs found which collocate with voler are caure and colgar (the sun) during the second half of the 13th century (examples $(2 a-c)$ ), two verbs which express actions with a highly foreseeable scheme that is well-known and linked to the inferential reading of signs. The catalogue is enlarged with the verbs començar ('to begin'), parir ('to give birth') or partir ('split') during the 14th, 15 th and 16 th centuries.

The examples are classified according to the type of subject that they contain:

a) [Human] subject, but without the ability to control the event; the verbs morir ('to die,' (11)) and parir ('to give birth,' (12)). The following examples reveal to us how this notion of 'intention' has been simply reduced to the idea of 'imminence': the act of giving birth - the same as that of dying-is not a wish, and neither does it depend on the subject's will; only a temporal reading can be 
made: the pregnant woman is about to give birth, the son is about to die. Some parallel examples with both verbs can be found in old French $(D M F)$.

(11) [...] una femna li vénc que avia un fil qui·s volia morir per so cor avia en la gola travessat un os [...]. (Vides de sants rosselloneses [s. XIIIb], 256, 24) 'He was visited by a woman who had a son who wanted to die because a bone was stuck in his throat'

(12) E lo bon Senyor, a les sues ovelles done comunament dues guardes: la una, lo pastor, açò és lo bon àngel. E quan lo li dóna? Tantost com la dona vol parir. (Vicent Ferrer, Sermons [s. XIVb], 51, 10)

'And the good Lord, commonly gives his sheep two guards: one, the shepherd, that is, the good angel. And when does he give it to them? As soon as the woman wants to give birth'

b) Impersonal sentences; the construction is especially used in contexts where the imminent situation appears as a 'show'; the periphrasis is often complemented by adverbial adjuncts or other constructions which stress the imminence of the action described by the infinitive: al punt que (13a), ja (13b):

(13) a. Disapte, a les set ores del vespre [...], al punt que's volia començar un torneo molt solemne que los cavallers avien concertat aprés de moltes festes [...] estava tot ple de gent, que casi no restava gent dins València. (Llibre d'Antiquitats de la Seu de València [XVId], 247, 3)

'Saturday, at seven pm [...], exactly when they wanted to begin a very solemn tournament that the knights had agreed to organize after many parties, it was so packed with people everywhere that there was hardly anybody left inside Valencia'

b. Geroniet: Pues anem a pendre puesto, que ya volen comenzar. (Carles Gassulla d'Ursino, Pensil celeste de flores [s. XVIIIa], 197, 23)

'Geroniet: Let us take a seat, that they already want to begin'

c) Non-human subject

(14) Volent eixir Nostre Amo de la iglésia, los músics pararen de sonar; i los balladors, balladores i demés concurrents a plaça la desocuparen [...]. (Rafael d'Amat i de Cortada, Calaix de sastre [s. XVIIIb], 0, 4850)

'Because the Sacred Host of the church wanted to leave, the musicians stopped playing and the male and female dancers and the other people present at the square left it empty'

It particularly often collocates with the subject sol [sun], in the context of the (sun)rise (15) and the (sun)set (colgar, pondre); see example (2a): 
(15) [...] la funció durà hasta allà cul de la nit, quan volia ia ratllar el dia, està dit tot. (Lluís de Galiana, Rondalla de rondalles [1767], 372, 13)

'The performance lasted until the early hours of the morning, when the day wanted to dawn'

Once again, it not only collocates with verbs referring to the solar cycle in Catalan but also in Old French $(D M F)$.

d) Metonymies/personifications

(16) Acabades que foren les robes dels catius e les galeres volien partir, Tirant ajustà tots los catius e convidà $\cdot 1$ s tots a dinar. (Joanot Martorell, Tirant lo Blanch [s. XVb], 422, 18)

'When the prisoners' clothes were finished and ready and the galleys wanted to leave, Tirant gathered all the prisoners and invited them to lunch.'

These contexts allow us to verify the presence of a preparatory-phase aspectual periphrasis in accordance with the classification made by Gavarró and Laca (2002: 2691-2696) and used by Montserrat (2012) for the classification of the Medieval Catalan aspectual periphrases appearing in Curial e Güelfa. Using the scheme designed by Gavarró and Laca (2002: 2691) shows us that:

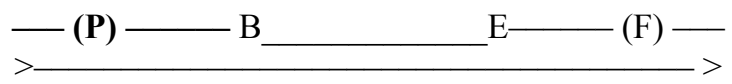

This scheme describes the development of the situation where (B) is the beginning, $(\mathrm{E})$ the ending, in addition to the time intervals which precede $(\mathrm{P})$ or follow (F) the realization of the situation. The phase which affects [voler Vinf] has been highlighted in bold: the preceding one, which does not include the beginning of the situation. To this should also be added a specific situation (D), «Decision», the moment when the subject orients his will to achieve the advent of the situation described by the infinitive. It would turn out to be like this:

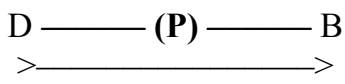

This preparation is conceived as a realization; in other words, a dynamic, durative and culminative dynamics (Pérez-Saldanya 2002) which starts with the decision and finishes with the realization of the situation uttered by the infinitive.

\subsection{From the expression of imminence to the expression of evidentiality}

Bybee, Pagliuca and Perkins formulate a hypothesis according to which early immediate futures in diachrony give rise to generic, mature futures linked to prediction; likewise, they derive into immediate futures strictly speaking which focus 
on imminence and are characterized by the fact that a predictive interpretation becomes difficult in them:

If immediate futures cannot be said to involve prediction, they may be regarded in either of two ways: as necessarily young futures, somewhere between proto-futures and a mature future with prediction as its core function; or, if not young, but rather established and stable, not strictly speaking futures at all, at least not in epistemic terms, amounting more to assertions announcing the imminence of an event rather than a prediction that it will take place. (Bybee, Pagliuca and Perkins 1994: 273)

If that diachronic description proposal is projected over the synchronic situation existing in Old Catalan, the cases of [voler Vinf] with imminence can be ordered in prototypicity terms, with a nucleus that has to do with the assertion of imminence rather than with prediction, and a transition periphery of prediction, epistemic modality and evidentiality. The core would be configured by those contexts where it is unlikely or impossible for the foreseen situation to be cancelled as imminent. That is the case of natural cycles (sunrise or sunset, example (15)) and vital ones (morir or parir, examples (11) and (12)), or scheduled events (començar, examples $(13 a, b))$. The internal dynamics of the situation implies that one can hardly expect a realization which is supposed to culminate with the advent of the aforesaid situation to be thwarted: once the day starts dawn, it is impossible for the sun not to rise. Seen from a different perspective, the certainty about the realization of the situation is absolute or nearly absolute (depending on the case as well) and, therefore, the utilization of the periphrasis does not imply an epistemic marking which modulates the speaker's commitment to the truth of the information uttered.

Instead, there is a second group of examples, equally old in the sample available to us, where the link between the signs on which the prediction is based and its fulfilment is not necessary, but only probable or possible. This refers particularly to the case of situations related to the weather (especially so with the infinitive ploure 'to rain') and the event caure 'to fall'; these are actually the two infinitives with which voler still collocates in present-day Catalan. Our focus at this point will be placed on the case of ploure and other weather-related situations, which have a stronger presence in the corpus and consequently make it possible to offer a more detailed explanation. ${ }^{7}$

Weather prediction implies higher uncertainty; therefore, making an assertion of the type vol ploure leads the addressee to interpret that the speaker is committed to the certainty of a prediction with some error margin. This circumstance means that evidential inference markers will very often be found accompanying the periphrasis, already since the first examples, which reinforce its prediction value. Therefore, semblar and parèixer ('parecer [to seem]') or indicar ('indicar' [to indicate], already in the 18th century) refer us back to signs as a strategy to free the speaker from the commitment to the truth of an utterance.

7. The $D M F$ also includes the construction il veut pleuvoir, although it is categorized as typical of Burgundy French. 
(17) a. [...] tota hora que veuràs espessetat de l'ayre e núvol e escuretat sequa que sembla que vulla ploure e 'ls núvols passen sens pluga. (Cànon d'Avicenna [s. XIVb], 66, 12)

'whenever you see thickness of the air and clouds and dry darkness, looking like it seems to want to rain and the clouds go past without rain'

b. Lo dia continuava no tan serè com los passats, pues que corrien algunes bromes que indicaven voler-se mudar lo temps [...]. (Rafael d'Amat i de Cortada, Calaix de sastre [s. XVIIIb], 0, 13503)

'The day continued not so clear as the previous ones, since there were some mists running which indicated that the weather wanted to change'

Associated with all of the above is the fact that several examples show us an attempt, a case where the realization of the foreseen situation has been cancelled (18), an ending that would be impossible in contexts such as that of the solar cycle.

(18) Dia 3 de març ha amanescut núvol, com volent ploure. Però tal qual goteta, i res més [...]. (Rafael d'Amat i de Cortada, Calaix de sastre [s. XVIIIb], 0, 9433) 'March 3rd has dawned cloudy, like wanting to rain. But only one drop fell and nothing else'

This contextual ambiguity - with such infinitives- might have favored semantic re-analysis. Therefore, it now expresses the prediction -which already implied the prospective value- from an evidential perspective, the imminence aspectual value being lost. This re-analysis can be checked in the definition provided by the $D D L C$, a descriptive dictionary of contemporary Catalan, of the construction [voler Vinf] (collocating with ploure and caure): 'presenting signs that something is bound to happen' ( $D D L C$, s.v. voler, 5$)$.

All the same, the notion of imminence still remains in the preceding examples (17) and (18), and it only disappears clearly in examples such as (19) where the negation shows that it does not have an aspectual value: it does not say that it was not about to rain (and that perhaps it would rain later on) but that, in accordance to the available signs, they foresaw that it would not rain. Imminence is not negated; instead, it is foreseen that a certain situation will not take place.

(19) Ý dien que era la occasió que lo virey que era havia llevat la taula de la Joca, que tenia en les banderes per a ell, ý de hallí a dos dies la tornà; ý paregué que no volia ploure, ni plogué per haver-la tornada. (Pere Joan Porcar, Dietari [s. XVIIa], 88, 19)

'And they said that it was the occasion, that the viceroy had taken off the table of la Joca [...] and two days later, he brought it back; and it seemed that it didn't want to rain, and it did not rain for having brought it back either'

And the aforementioned re-analysis becomes especially visible in example (20), which no longer refers to the advent of a situation (the rain) according to the signs 
available, but a continuation of this situation which already takes place at the time of the enunciation.

(20) A quarts de deu continuava la pluja, rajant un poc les canals; i apar que vol continuar en tota la nit. (Rafael d'Amat i de Cortada, Calaix de sastre [s. XVIIIb], 0, 12145)

'The rain continued after ten, trickling a little along the canal; and it seems to want to continue all night long'

Thus, the periphrasis finally loses the aspectual value. Now there is a construction with an epistemic/evidential value; it expresses the speaker's belief that a specific event will happen in the future, in parallel to other evidential markers such as amenazar [to threaten] and prometer [to promise] in Spanish, studied by Cornillie (2007). However, it is worth highlighting that, even though this idea of immediate advent is lost, the idea that it is projected over a near future («en tota la nit») does remain. This is how the DLabèrnia, drawn up in the first half of the 19th century, presents this periphrasis with voler: 'something is about to be or to be verified, like vol ploure' (s.v. voler): despite suggesting the imminence aspectual value ('estar próximo a ser'), the lexicographer is forced to complete the definition with the incorporation of a prediction ('estar próximo a verificarse').

It is possible to find examples identical to those found in the text by the Baró de Maldà in today's Catalan, which proves that the new meaning identified in the late 18 th century is the one that has survived to the present day:

(21) a. A hores d'ara portem ja $10 \mathrm{~mm}$ acumulats de precipitació i sembla que vol continuar plovent unes quantes hores més. $(2008)^{8}$

'By now we already have accumulated $10 \mathrm{~mm}$ of rainfall and, seemingly, it wants to keep on raining for a few more hours'

b. Desde el migdia que està plovent de forma continuada a Manresa [...] i sembla segons el radar que vol continuar plovent!!! (2009) ${ }^{9}$

'It has been raining non-stop in Manresa since midday [...] and it seems according to the radar that it wants to continue raining!!'

Therefore, the imminence aspectual periphrasis, specialized in weather-related contexts, has been re-analyzed and it codes the meaning 'show signs that something is bound to happen' ( $D D L C$, s.v. voler, 5). A process culminated in the late 18 th century through which voler has ended up becoming fixed as a locution used in weather predictions, more precisely about rain. This grammaticalization process entails a progressive deepening of subjectivity in the construction, insofar as «the development of epistemic and evidential meanings increases the coding of speaker informativeness about his or her attitude» (p. 49), in parallel to the trajectory described by

8. Retrieved from: <http://meteovallirana.blogspot.com.es/2008_04_01_archive.html>

9. Retrieved from: $<$ http://blogs.ccma.cat/eltemps.php?itemid $=2039 \overline{5}>$ 
other verbs which have become inference markers as a result of a subjectivization process; it is the case of the Spanish verbs parecer, resultar, prometer and amenazar, (Cornillie 2007) or olerse (Fernández Jaén 2008); or, in Catalan, the verbs estimar and esmar, (Martines 2013 and forthcoming a), (a)parer (Antolí-Martínez 2012), Sentí and Antolí-Martínez (2013), témer (Antolí-Martínez forthcoming), etc.

\section{Conclusions}

The constructions vol ploure and vol caure in present-day Catalan are only a remainder of the imminence aspectual periphrasis that the verb voler constituted in Old and Modern Catalan. This same aspectual periphrasis is known to other Romance languages, at least in medieval times; it is the case of Occitan, FrancoProvençal, French or Italian. The interest of this construction in today's language lies in the fact that, as a consequence of a contextual re-analysis and the coding of the corresponding discursive implicature (following Traugott 2012 and Traugott and Trousdale 2013), this structure, saturated with the infinitives ploure or caure will assume an epistemic/evidential value from the modern era onwards (17th and 18 th centuries) that will reach the present-day language (DDLC, s.v. voler, 5).

In accordance with our proposal, which in turn results from adapting a number of other previous ones (Aijmer 1985; Traugott 1989; Bybee, Pagliuca and Perkins 1994; or Narrog 2012) to the reality of our corpus of examples (extracted from the $C I G C A$ and from the CIGCMod), the process followed by the periphrasis [voler Vinf] from Classical Latin and until present-day Catalan looks like this:

\section{DESIRE $>$ INTENTION $>$ IMMINENCE (prospective aspect) $>$ EPISTEMICITY / EVIDENTIALITY}

As seen above (DLewis), the volitive periphrasis is already known to Classical Latin. The origin of the imminence periphrasis, however, does have to be found in the Romance stage, but the pre-literary one. Clear examples are identified in Catalan ever since the second half of the 13th century. It is only possible for us to suppose what the process must have been like with the examples found in the old language -and thanks to theoretical concepts such as gradualness, semantic bleaching, semantic and syntactic re-analysis or invited inference (Traugott 2012). Based on all that, our proposal contains two possible paths towards the expression of imminence that imply a lessening of the subject's potential agentivity: on the one hand, one could pass from 'intention' to 'imminence' thanks to transition contexts where the subject's agentivity is reduced for whatever reason (routine actions, impersonal sentences, mediate intention); a second explanation, compatible with the preceding one, is that an intermediate meaning could exist between 'intention' and 'imminence': 'direction, trajectory,' derived from the former, which has been checked in Catalan, and where the subject may be inanimate.

Finally, our paper has offered a characterization in prototypicity terms of the examples found of the aspectual periphrasis [voler Vinf], with a nucleus where the verb appears next to infinitives describing situations which can hardly be 
cancelled and, on the periphery, those examples where voler is accompanied by infinitives the realization of which entails a higher degree of uncertainty. These last examples provide an ambiguity that turns them into bridging contexts for the displacement of the meaning towards the epistemic modality and evidentiality (it would be the case of caure and of all those infinitives which have to do with the weather). The epistemic/evidential re-analysis of the periphrasis, saturated with these infinitives, together with the coding of the new value (as collected in the $D D L C$, s.v. voler, 5) culminate a grammaticalization process which, characterized by a progressive semantic bleaching (of both the volitive and the aspectual values) and by a growing subjectivization (following the definition proposed by Traugott and Dasher 2010), places the verb voler next to other inference evidential markers.

\section{References}

Aijmer, Karin (1985). «The semantic development of will». In: Fisiak, Jacek (ed.). Historical Semantics. Berlin: Mouton, pp. 11-21.

Antolí-Martínez, Jordi M. (2012). «Canvi semàntic i gramaticalització en el sorgiment de marcadors evidencials. Evolució semàntica de PARERE i derivats en el llatí tardà i en el català antic (s. III-XVI)». eHumanista/IVITRA 2: 41-84.

Antolí-Martínez, Jordi M. (forthcoming). «El surgimiento de un evidencial de inferencia en catalán medieval. El verbo témer entre los siglos XIII y XV». eHumanista/ IVITRA 7.

Bybee, Joan L.; Pagliuca, William; Perkins, Revere D. (1991). «Back to the Future». In: Traugott, Elisabeth C.; Heine, Bernd. (eds.). Approaches to Grammaticalization: Volume II. Types of grammatical markers. Amsterdam: John Benjamins, pp. 17-58.

Bybee, Joan L.; Pagliuca, William; Perkins, Revere D. (1994). The evolution of grammar: tense, aspect, and modality in the languages of the world. Chicago: University of Chicago Press.

$C I G C A$ = Martines, Josep; Martines, Vicent (dirs.). "Corpus Informatitzat de la Gramàtica del Català Antic». In Corpus Informatitzat Multilingüe de Textos Antics $i$ Contemporanis (CIMTAC). Alacant: ISIC-IVITRA.

Cornillie, Bert (2007). Evidentiality and Epistemic Modality in Spanish (Semi-) Auxiliaries. Berlin/New York: Mouton de Gruyter.

DAcadémie $=$ Atilf ; Académie Française. Dictionnaire de l'Académie française, neuvième édition. <http://atilf.atilf.fr/academie9.htm>.

DAguiló = Aguiló i Fuster, Marian (1914-1934). Diccionari Aguiló. Barcelona: Institut d'Estudis Catalans.

DCantalausa $=$ Cantalausa, Joan de (2003). Diccionari general occitan . Rodez: Edicions Cultura d'Oc.

$D C V B=$ Alcover, Antoni M.; Moll., Francesc de B. (1985). Diccionari CatalàValencià-Balear. Palma de Mallorca: Moll.

$D D L C=$ Rafel, Joaquim (dir.). Diccionari descriptiu de la llengua catalana. Barcelona: Institut Estudis Catalans. $<$ http://dcc.iec.cat/ddlc/index.asp $>$.

DECat $=$ Coromines, Joan (1995). Diccionari etimolòic $i$ complementari de la llengua catalana. Barcelona: Curial Edicions Catalanes/La Caixa. 
DFaraudo = Faraudo de Saint-Germain, Lluís Vocabulari de la Llengua Catalana Medieval de Lluís Faraudo de Saint-Germain. Barcelona: Institut d'Estudis Catalans. $<$ http://www.iec.cat/faraudo/default.asp\#top $>$.

DGodefroy = Godefroy, Frédéric (1880-1902). Dictionnaire de l'ancienne langue française et de tous ses dialectes du IXe au XVe siècle. Paris.

$\operatorname{Dicod}^{\prime} \mathrm{O}_{c}=$ Lo Congrès permanent de la lenga occitana. Dicod'Òc. Multidictionnaire occitan. $<$ http://www.locongres.org/index.php/fr/applications/dicodoc-fr/dicodocrecherche>.

DIEC2 = Institut d'Estudis Catalans (2007). Diccionari de la Llengua Catalana. Barcelona: Edicions 62 / Enciclopèdia Catalana.

DLabèrnia $=$ Labèrnia, Pere (1839). Diccionari de la llengua catalana. Barcelona: Estampa dels Hereus de la Vda. Pla.

DLevy $=$ Levy, Emil (1909). Petit dictionnaire provençal-français. Heidelberg.

DLewis = Lewis, Charlton T.; Short, Charles (1879). A Latin Dictionary. Oxford: Oxford University Press.

$D M F=$ ATILF ; CNRS ; Université de Lorraine (2010). Dictionnaire du Moyen Français. $<$ http://www.atilf.fr/dmf $>$.

Fernández Jaén, Jorge (2008). «Modalidad epistémica y sentido del olfato: la evidencialidad del verbo oler». Estudios de Lingüística Universidad de Alicante 22: 65-89.

Gavarró, Anna; Laca, Brenda (2002). «Les perífrasis temporals, aspectuals i modals». In: Solà, Joan; Lloret, Maria-Rosa; Mascaró, Joan; Pérez-Saldanya, Manuel (eds.). Gramàtica del Català Contemporani, vol. 3. Barcelona: Editorial Empúries, pp. 2663-2726.

GDIU = De Mauro, Tullio (2008). Grande dizionario italiano dell'uso. Torino: UTET.

Hopper, Paul; Traugott, Elisabeth C. (1993). Grammaticalization. Cambridge: Cambridge University Press.

Martines, Josep (2013). «El verb estimar i l'amor hereós i Joan Roís de Corella. Un acostament segons la pragmàtica diacrònica». Afers 76: 717-739.

Martines, Josep (forthcoming $a$ ). «Diacronia i neologia: canvi semàntic, subjectivació i representació del pensament. El català esmar, des de 'taxar' fins a 'inferir' i 'imaginar' i més enllà». Caplletra: Revista Internacional de Filologia.

Martines, Josep (forthcoming $b$ ). «Une approche du futur épistémique du catalan médiéval: les premiers pas (XIII s.)». In: Baranzini, Laura; Sánchez Méndez, Juan ; de Saussure, Louis (eds.). Le futur dans les langues romanes. Université de Neuchâtel.

Montserrat, Sandra (2012). «Les perífrasis aspectuals en el Curial e Güelfa». In: Ferrando, Antoni (ed.). Estudis lingüístics i culturals sobre Curial e Güelfa. Amsterdam: John Benjamins, pp. 649-670.

Narrog, Heiko (2012). Modality, subjectivity, and semantic change: a cross-linguistic perspective. Oxford: Oxford University Press.

Pérez-Saldanya, Manuel (1998). Del llatí al català: Morfosintaxi verbal histórica. València: Universitat de València.

Pérez Saldanya, Manuel (2008). «Les relacions temporals i aspectuals». In: Solà, Joan; Lloret, Maria-Rosa; Mascaró, Joan; Pérez-Saldanya, Manuel (eds.). Gramàtica del Català Contemporani, vol. 3. Barcelona: Editorial Empúries, pp. 2571-2664.

Pinkster, Harm (1985). «The Development of Future Tense Auxiliaries in Latin». Glotta 63: 186-208. 
Provenzalisches Supplement = Levy, Emil (1898). Provenzalisches Supplementwörterbuch. Leipzig.

Schmid, Beatrice (2012). «Un aspecto sintáctico del Curial e Güelfa. Las perífrasis modales». In: Ferrando, Antoni. (ed.). Estudis lingüistics i culturals sobre Curial e Güelfa. Amsterdam: John Benjamins, pp. 843-874.

Schulte, Kim (2007). Prepositional infinitives in Romance. A Usage-Based Approach to Syntactic Change. Berna: Peter Lang.

Sentí, Andreu (2010). «La perífrasi deure + Inf en el català preliterari. Gènesi i evolució d'una perífrasi romànica en el seu context lingüístic». In: Actes del XV Col·loqui de l'Associació Internacional de Llengua i Literatura Catalanes. Barcelona: Publicacions de l'Abadia de Montserrat, pp. 107-124.

Sentí, Andreu (2013). Gramaticalització i subjectivació de la modalitat en català antic: un estudi de corpus de les perifrasis verbals $<$ deure $+I N F>i<$ haver (a/de) + $I N F>$. University of Alicante, doctoral dissertation.

Sentí, Andreu; Antolí-Martínez, Jordi M. (2013). «La inferència en l'aflorament dels valors evidencials en català antic». Caplletra: Revista Internacional de Filologia 55: 157-183.

TLFI = Trésor de la Langue Française informatisé (2004). París: CNRS Éditions. $<$ http://atilf.atilf.fr $>$.

Traugott, Elisabeth C. (2010). «Revisiting subjectification and intersubjectification». In: Davidse, Kristin; Vandelanotte, Lieven; Cuyckens, Hubert (eds.). Subjectification, Intersubjectification and Grammaticalization. Berlín/New York: De Gruyter Mouton, pp. 29-70.

Traugott, Elisabeth C. (2012). «Pragmatics and language change». In: Allan, Keith; Jaszczolt, Kassia. (eds.). The Cambridge Handbook of Pragmatics. Cambridge: Cambridge University Press, pp. 549-565.

Traugott, Elisabeth; Dasher, Richard (2002). Regularity in Semantic Change. Cambridge: Cambridge University Press.

Traugott, Elisabeth; Trousdale, Graeme (2013). Constructionalization and Constructional Changes. Oxford: Oxford University Press.

Vendler, Zeno (1957). «Verbs and times». The Philosophical Review 66.2: 143-160.

VTreccani $=$ Istituto dell'Enciclopedia Italiana. Vocabolario Treccani. $<$ http://www. treccani.it/vocabolario/>. 